International Journal of Engineering \& Technology, 7 (2.29) (2018) $921-926$
International Journal of Engineering \& Technology
SPC
Website: www.sciencepubco.com/index.php/IJET
Research paper

\title{
The Rise of Groundwater Due to Rainfall and the Control of Landslide by Zero-Energy Groundwater Withdrawal System
}

\author{
Shamsan Alsubal ${ }^{1}$, Nasiman Sapari², Indra S.H. Harahap ${ }^{3 *}$ \\ ${ }^{1,2,3}$ Department Of Environmental And Civil Engineering, Universiti Teknologi Petronas,Perak, Malaysia \\ *Corresponding Author E-Mail: Indrasati@Utp.Com.My
}

\begin{abstract}
Slope failure is a common issue in tropical countries. The rise of groundwater table due to rainfall is one of the main triggering factors. There are several methods for slope stabilization such as soil nailing, retaining walls, cut and fill, vegetation and so on. Most of those methods are costly and we are in need for stabilizing methods that are more economical and easier to construct. This article introduces a new method for slope stability. This method is examined numerically and experimentally. It is represented in an automatic zero-energy groundwater withdrawal system to enhance slope stability. The system is validated in a pre-fabricated model to ensure that it works on natural soil slope. The numerical simulation is performed in Soilworks software with coupled seepage-slope stability analysis using finite element methods to check the safety factor with and without the system. The effectiveness of this method is investigated with various rainfall intensities and soil permeabilities. The results for slopes with the application of groundwater withdrawal system are compared with the results without the system. The results demonstrate the effectiveness of the proposed method in reducing groundwater table and enhancing slope stability. The factor of safety for the slope with high soil permeability drops from 1.312 before the rainfall to 1.292 and 0.93 after the third rainfall event for the slope with and without pumping groundwater respectively. For soil slope with moderate soil permeability, the factor of safety deteriorates from 1.314 to 1.157 at the end of the third day, while it remains stable with pumping groundwater. Matric suction is highly increased at the crest of the slope due to pumping.
\end{abstract}

Keywords: slope stability; rainfall infiltration; groundwater table

\section{Introduction}

Slope failures have been identified as one of the most frequent natural disasters. The rise of groundwater due to infiltration of rainwater is a major triggering factor for slope failure [1-3]. The soil permeability affects the rainfall infiltration within unsaturated soil $[2,4]$. Soil with higher permeability allows more rainwater to infiltrate and flow into the soil slope resulting in a quick change of pore-water pressure from negative to positive [5]. The infiltration of rainwater increases water content and decreases matric suction in the soil [6-9]. During rainfall, soil suction dissipates due to the saturation of the soil. Failure would happen because of positive pore-water pressure development [10]. The factor of safety increases with the increase of matric suction $[11,12]$.

When the rainfall intensity is greater than the soil permeability $\left[k_{s}\right]$, it infiltrates initially by higher infiltration rate than $k_{s}$, by as much as 3.5 times. Then it declines over time towards the steady state conditions [13]. However, when the rainfall intensity is less than $k_{s}$, the initial infiltration is low at the crest of the slope but rises gradually towards the steady state conditions [13]. Low-intensity rainfall for long duration is more probable to induce soil surface failure than intense rain due to the low suction in the first 20-50 $\mathrm{cm}$ of the first layer of soil [14]. Heavy and prolonged rainfall decreases the seepage rate [15]. A study was conducted on the mechanism of $13 \mathrm{~h}$ duration rainfall induced landslide in Shenzhen due to the prolonged rainfall and the highly permeable outcrops with good storability of the weathered granite. The rainwater continued to seep to the fill layer even after the rainfall has stopped, and the groundwater table rose and eventually triggered the landslide [16].

During rainstorm, the ground water table rises and results in shallow landslide [2, 17]. Heavy rainstorm results in developing a perched water table and significant rise of ground water table [7, $18,19]$. The groundwater softens the slope-forming material, reduces the slope's shear strength, and pore water pressure turns into positive [20]. A landslide in Putrajaya, Malaysia, buried 23 vehicles and forced 1000 people to evacuate. The failure was induced by the rise of groundwater table two days after a $210 \mathrm{~mm}$ intensive rainfall event [21].

Horizontal drains have been used for reducing groundwater table which are effective when they attract the majority of groundwater table [22]. Horizontal drains reduce the pore pressure on the slip surface while the drainage rate increases with increasing the length of the drains [23]. The horizontal drains length is far more effective than the spacing between them, the minimum length is $22.5 \mathrm{~m}[21,24]$. The best place for installing horizontal drains is at the toe of the slope [21,22].

Drain trenches are used to decrease the groundwater table and avoid the impact of pore water pressure during wet seasons [25]. The most important design element is the distance between trenches to avoid the critical effect of heavy rainfall and improve the capability of drain trenches [26].

Seepage velocity increases with the increase of void ratio and rainfall intensity, and it is significantly high in soil compacted at low density [27]. A landslide in a reservoir located in Sichuan province, China, is associated with the water level drop of the 
reservoir. The landslide occurred due to the seepage forces caused by the difference between the groundwater level in the slope and water level of the reservoir [28]. Because of the limitation of soil slope permeability, the drop of the reservoir water level was faster than the groundwater level at the slope. Therefore, the seepage pressure in the slope mass increased and the deformation started.

The suction and degree of saturation can be considered as indicators of the safety state of the slope. The matric suction of the soil slope can be affected by single rainfall event at the top part of the soil cover, however, the deeper part of the soil is not affected by an individual rainfall event and affected by seasonal trend [29]. Slope failure in a dry and permeable soil happens due to the increase of moisture content, advancement of wetting front, and the perched water table development. However, the failure of low permeability soil slope is due to the increase of volumetric moisture content with the advancement of wetting front [30].

In experimental study on factors that initiate slope failure, it was observed that failure would occur when the soil near the lower part of the slope becomes almost fully saturated even the other parts remain partially saturated. The loose soil slope fails faster than dense soil slope because of the high strength and low permeability of the dense slope. Furthermore, rainwater infiltration is not enough to trigger slope failure, rather generation of pore-water pressure from the increase in moisture content associated with the rise of ground water level is the one that create an unstable zone. The saturation at the upper part of the slope increases with rainfall and decreases after the rainfall due to the rainwater drain out. The degree of soil saturation depends on the slope steepness where it was less in steeper slopes [31]. The slope failure occurs at different periods of rainfall owing to the enhancement of pore-water pressure and the decrease in shear strength. The increase in porewater pressure is governed by the permeability of soil slope and the rate of increase is related to the degree of inclination of the slope [15].

To conclude that, the rise of groundwater table due to rainfall could trigger landslide. It increases the pore pressure on the slip surface and reduce the shear strength of the soil. Horizontal drains and drain trenches have been used in order to avoid the impact of groundwater above the toe of the slope. The limitation of horizontal drains is that, the groundwater table can not be lowered below the toe of the slope which may not avoid the impact of groundwater table during heavy rainstorm and the quick rise of groundwater level. Furthermore, the minimum length of horizontal drains is more than $20 \mathrm{~m}$. Therefore, this paper presents a new method of lowering water table below the toe of the slopes.

The objectives of this paper are to study the influence of the rise of groundwater table in triggering landslide, examine numerically a new method of groundwater withdrawal system to enhance slope stability and verify experimentally the capability of the system to work on a natural soil slope.

\section{Methodology/Materials}

This paper focuses on the effect of rainfall induced landslide in which, the effect of the rise of ground water table with respect to rainfall intensity and soil permeability is identified. Pumping groundwater method is examined numerically and experimentally and compared with slope conditions without pumping. The rain is applied at far field from the area having potential slope failure with different rainfall intensities. This study is based on numerical analysis in which a coupled seepage-slope stability analysis is carried out by Soilworks software using Finite Element Method and Limit Equilibrium method.

\subsection{Soil Properties}

The soil properties are taken from the lab experiments for soil case studies located in Malaysia and reported by [32] at University Technology Malaysia, Skudai Campus, namely Bukit Cerapan. Table 1 shows the physical properties of the soil.
Table 1: Soil properties

\begin{tabular}{|l|c|c|c|c|c|c|} 
Composition & Sand & Silt & Clay & PI & Cohesion & Gs \\
\hline
\end{tabular}

\begin{tabular}{|c|c|c|c|c|c|c|}
\hline Sandy silt & $33 \%$ & $34 \%$ & $33 \%$ & 27.4 & $7.6 \mathrm{Kpa}$ & 2.63 \\
\hline
\end{tabular}

The soil has a hydraulic conductivity of 5.00E-7, saturated volumetric water content is $45 \%$, a residual volumetric water content is $33 \%$, specific gravity 2.63 , cohesion equals to $7.6 \mathrm{kpa}$ and friction angle of $32^{\circ}$. The parameters used for predicting hydraulic conductivity functions of soils using Van Genuchten method are as in table 2 .

Table 2: Van Genuchten fitting parameters for predicting hydraulic conductivity function

\begin{tabular}{|l|l|l|l|l|}
\hline Parameter & $\boldsymbol{\alpha}$ & $\mathbf{n}$ & $\mathbf{m}$ & $\boldsymbol{K}_{\text {sat }}$ \\
\hline Soil & 0.178 & 1.966 & 0.491 & $5 \mathrm{e}-7$ \\
\hline
\end{tabular}

A homogeneous soil slope model is designed, with $1.00 \mathrm{Km}$ long, $0.200 \mathrm{Km}$ height and $45^{\circ}$ slope angel. A ground water table is specified which is $5 \mathrm{~m}$ deep at the toe of the slope. The slope model is underlined with an impermeable layer as shown in Fig. 1. The raining zone is assumed to be limited at Zone 1 [300 m] and the slope stability check is allocated at Zone 3 . This design enables us to study the effect of surrounding topography on slope stability and to study the infiltration of rainwater through long and deep distance as well as the effect of rain intensity on the rise of deep groundwater table. A ten-meter long sub-horizontal well [ $45^{\circ}$ to the horizontal] is located at the toe of the slope.

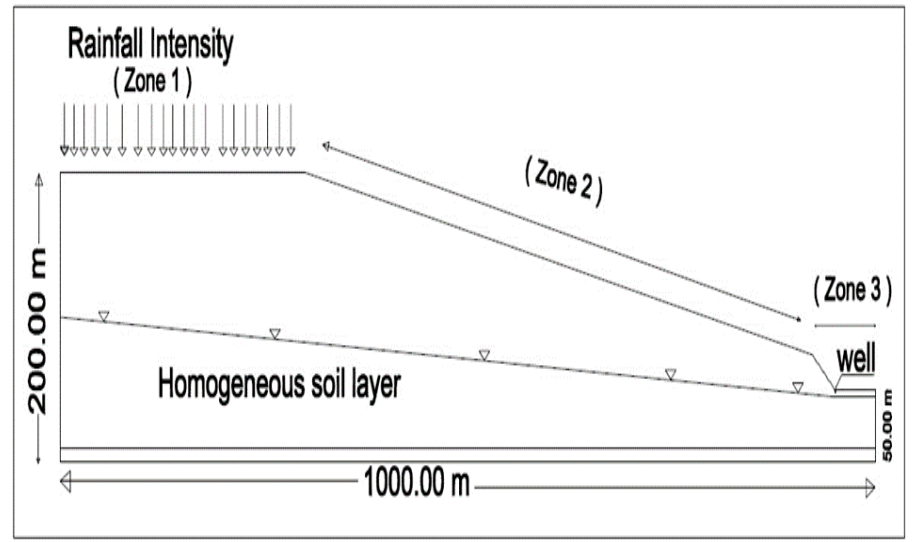

Fig. 1: Prototype cross section

\subsection{Experiment's Equipment and Procedures}

A prototype model is fabricated for laboratory verification of siphoning method as shown in Fig 2 and 3. The procedures of the laboratory experiment are as follow:

1- Soil sample is collected and oven dried for 24 hours

2- The cylinder is filled with soil until point $\mathrm{B}$ and the reservoir is filled with water

3- The valve is open to allow the water flow through the sample

4- When the water level reaches point $\mathrm{c}$, it automatically flows and discharges at point $\mathrm{D}$.

5- After that, the valve is closed.

6- The flow at point $\mathrm{D}$ and the decrease of water level is monitored

7- The pipe at point $\mathrm{D}$ is extended to a level parallel to point $\mathrm{A}$.

8 - The steps $4-6$ are repeated, the decrease of water level and the flow at the end of the pipe are monitored.

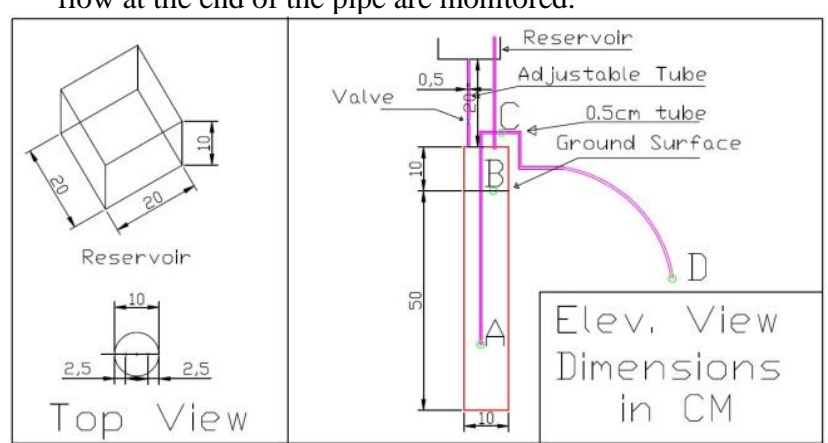

Fig. 2: Prototype of the prefabricated model 


\subsection{Rainfall Boundary and Scenarios}

The rainfall is specified at Zone 1 along $300 \mathrm{~m}$ of the slope model. The rainfall intensity varies from low intensity of $0.2 \mathrm{~m} /$ day to high intensity of $0.6 \mathrm{~m} /$ day with different soil permeability ranging from very permeable soil with $k_{s}=1 \mathrm{E}-5 \mathrm{~m} / \mathrm{s}$ to low permeable soil with $\mathrm{ks}=1 \mathrm{E}-7 \mathrm{~m} / \mathrm{s}$. The time stages of rainfall are specified for three days in a rainfall period of $6 \mathrm{hrs} /$ day, which are sufficient for the study of the variation of groundwater level [Please refer to table 3]. Figure 1 illustrates the distribution of rain along a homogeneous slope. The maximum negative pore water pressure in the slope model is $20 \mathrm{KN} / \mathrm{m}^{2}$. A well at the toe of the slope is specified and a negative flux boundary is applied to the well boundary representing pumping rate during the rise of the groundwater table. The negative flux rate is the same value of soil permeability in each scenario to get the lowest seepage through well boundaries. Table 3 shows the rainfall functions for rainfall intensity within the rainfall period for low, moderate, and high intensities. Table 4 shows the scenarios of rain intensity, soil permeability, and pumping rate. Nine scenarios are analyzed without pumping to represent the natural condition of the slope and nine scenarios are analyzed with pumping.

Table 3: Rainfall functions

\begin{tabular}{|c|c|c|c|c|c|}
\hline \multicolumn{2}{|c|}{ Low Rain intensity } & \multicolumn{2}{c|}{ Moderate Rain Intensi- } & \multicolumn{2}{l|}{ High Rain Intensity } \\
ty & $\begin{array}{c}\text { Value } \\
\text { [m/day }]\end{array}$ & Day & $\begin{array}{c}\text { Value } \\
{[\mathbf{m} / \text { day }]}\end{array}$ & Day & $\begin{array}{c}\text { Value } \\
{[\mathbf{m} / \text { day }]}\end{array}$ \\
\hline Day & 0.2 & 0.00000 & 0.4 & 0.00000 & 0.6 \\
\hline 0.00000 & 0.2 & 0.25000 & 0.4 & 0.25000 & 0.6 \\
\hline 0.25000 & 0 & 0.25001 & 0 & 0.25001 & 0 \\
\hline 0.25001 & 0 & 1.00000 & 0 & 1.00000 & 0 \\
\hline 1.00000 & 0.2 & 1.00001 & 0.4 & 1.00001 & 0.6 \\
\hline 1.00001 & 0.2 & 1.25000 & 0.4 & 1.25000 & 0.6 \\
\hline 1.25000 & 0 & 1.25001 & 0 & 1.25001 & 0 \\
\hline 1.25001 & 0 & 2.00000 & 0 & 2.00000 & 0 \\
\hline 2.00000 & 0.2 & 2.00001 & 0.4 & 2.00001 & 0.6 \\
\hline 2.00001 & 0.2 & 2.25000 & 0.4 & 2.25000 & 0.6 \\
\hline 2.25000 & 0 & 2.25001 & 0 & 2.25001 & 0 \\
\hline 2.25001 & 0 & 3.00000 & 0 & 3.00000 & 0 \\
\hline 3.00000 & & \multicolumn{3}{|c}{} \\
\hline
\end{tabular}

Table 4: Rainfall intensity, soil permeability, and pumping rate scenarios

\begin{tabular}{|c|c|c|c|}
\hline No & $\begin{array}{c}\text { Rainfall intensity } \\
{[\mathbf{m} / \mathbf{d a y}]}\end{array}$ & $\begin{array}{c}\text { Pumping rate } \\
{[\mathbf{m} / \mathbf{d a y}]}\end{array}$ & $\begin{array}{c}\text { Coefficient of permea- } \\
\text { bility }[\mathbf{m} / \mathbf{s e c}]\end{array}$ \\
\hline 1 & 0.2 & 0 & $\mathrm{Ks}=1 \mathrm{E}-5$ \\
\hline 2 & 0.2 & 0 & $\mathrm{Ks}=1 \mathrm{E}-6$ \\
\hline 3 & 0.2 & 0 & $\mathrm{Ks}=1 \mathrm{E}-7$ \\
\hline 4 & 0.4 & 0 & $\mathrm{Ks}=1 \mathrm{E}-5$ \\
\hline 5 & 0.4 & 0 & $\mathrm{Ks}=1 \mathrm{E}-6$ \\
\hline 6 & 0.4 & 0 & $\mathrm{Ks}=1 \mathrm{E}-7$ \\
\hline 7 & 0.6 & 0 & $\mathrm{Ks}=1 \mathrm{E}-5$ \\
\hline 8 & 0.6 & 0 & $\mathrm{Ks}=1 \mathrm{E}-7$ \\
\hline 9 & 0.6 & 0 & $\mathrm{Ks}=1 \mathrm{E}-5$ \\
\hline 10 & 0.2 & -0.864 & $\mathrm{Ks}=1 \mathrm{E}-6$ \\
\hline 11 & 0.2 & -0.0864 & $\mathrm{Ks}=1 \mathrm{E}-7$ \\
\hline 12 & 0.2 & -0.00864 & $\mathrm{Ks}=1 \mathrm{E}-5$ \\
\hline 13 & 0.4 & -0.864 & $\mathrm{Ks}=1 \mathrm{E}-6$ \\
\hline 14 & 0.4 & -0.0864 & $\mathrm{Ks}=1 \mathrm{E}-7$ \\
\hline 15 & 0.4 & -0.00864 & $\mathrm{Ks}=1 \mathrm{E}-5$ \\
\hline 16 & 0.6 & -0.864 & $\mathrm{Ks}=1 \mathrm{E}-6$ \\
\hline 17 & 0.6 & -0.0864 & \\
\hline 18 & 0.6 & -0.00864 & $\mathrm{~K}-7$ \\
\hline
\end{tabular}

\section{Results and Findings}

\subsection{Experiment Findings}

The result proves the effectiveness of the method used; the pumping started automatically after the water level rises to a level of point $C$ [Please refer to Fig. 2] and continues to pump out the water from the soil after closing the Valve. It reduces the water level to a level parallel to point $\mathrm{D}$ before extending the pipe at point $\mathrm{D}$. The pipe is extended to a level parallel to level A and the steps are repeated, the water level drops to the point A. The pumping discharge increases with the increase of pore-water pressure where high pore-water pressure increases the pumping rate. In other words, the drainage rate increases with increasing the pore pressure. The experiment conducted on a soil having an average permeability of $1.1575 \mathrm{e}-7 \mathrm{~m} / \mathrm{s}$ as shown in Fig 3 .

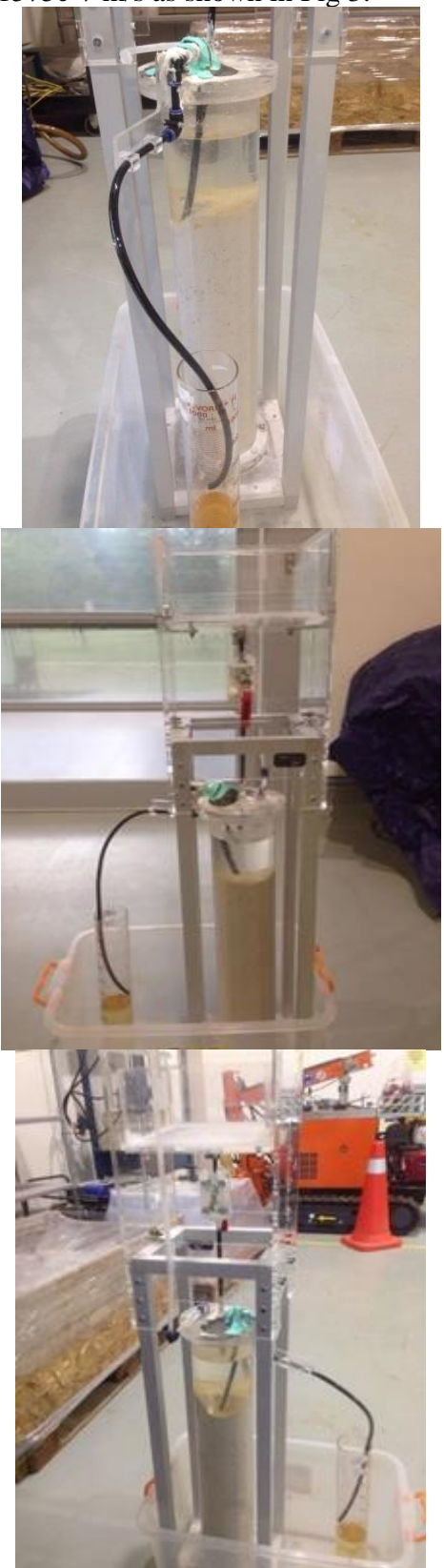

Fig. 3: Overview of the experimental apparatus while running the experiment

\subsection{The Rise of Groundwater Table}

The groundwater table rises symmetrically with all rainfall intensities because the infiltration of rainwater declines with the depth and almost the same quantity of rainwater reaches the groundwater table. The groundwater table rises rapidly with high permeability soil slope; it rises up to $9.69 \mathrm{~m}$ at the end of the first day and $10.61 \mathrm{~m}$ above the initial groundwater level at the end of the third day at Zone 3 as shown in Fig. 4. The rise of groundwater table causes the factor of safety of the slope at Zone 3 to drop from 1.312 to 0.95 at the end of the first day and 0.93 at the end of the third day. On the other hand, pumping groundwater table at Zone 3 keeps the groundwater as low as the depth of the pumping well. As a result, the factor of safety remains almost constant, it drops slightly from 1.317 to 1.294 at end of the first day due to the advancement of groundwater from Zone 2 which touches the slip 
surface at the middle of the slip surface and remains stable till the end of the third day .

For the slope with moderate soil permeability, the groundwater table rises $3.28 \mathrm{~m}$ at the end of the first day and $5.87 \mathrm{~m}$ above the toe of the slope at the end of the third day as shown in Fig. 5. It decreases the factor of safety of the slope from 1.314 to 1.157 at the end of the third day. On the other hand, pumping groundwater systems keeps the groundwater below the depth of the pumping well and the factor of safety remains constant [look at Fig. 8]

For the slope with low soil permeability, the rise of groundwater table is slight. It rises $1.22 \mathrm{~m}$ above the initial groundwater table for slope without pumping while it remains below the well's depth with pumping system as shown in Fig. 6]. The factor of safety remains constant in both cases because the groundwater does not touch the slip surface.

Figures 4-8 show the the rise of groundwater table with pumping and without pumping of groundwater. It can be seen that the groundwater rises above the initial groundwater level along Zone 1,2 and 3. The groundwater table at Zone 3 with slopes simulated with pumping boundaries is below the toe of the slope while slope simulated without pumping is above the toe of the slope.

Pumping of groundwater has a great effect on reducing water table and increasing the matric suction to enhance slope stability. This effect is directly proportional to the depth of the drawdown and the number of wells that could maintain high seepage rate at the deepest point of the drawdown. The higher number of connected wells the faster withdrawal of groundwater table.

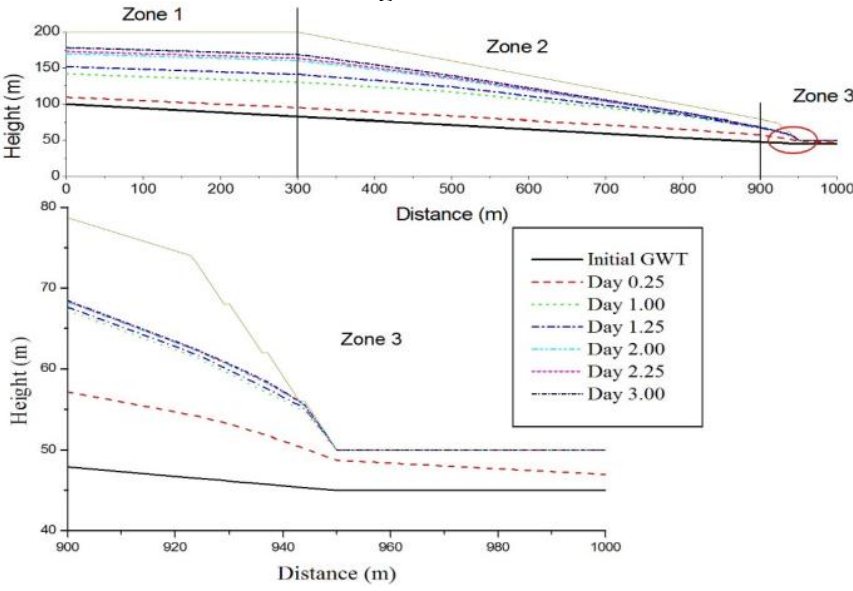

Fig. 4: The rise of GWT after $0.2,0.4, \& 0.6 \mathrm{~m} /$ day rainfall intensity in soil of $1 \mathrm{E}-5 \mathrm{~m} / \mathrm{sec}$ permeability.

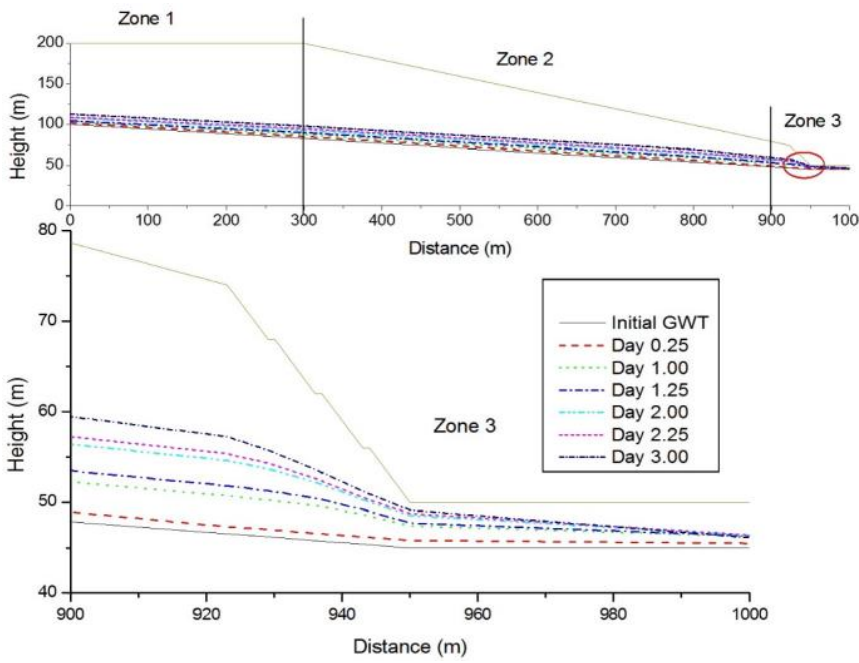

Fig .5: The rise of GWT after $0.2,0.4, \& 0.6 \mathrm{~m} /$ day rainfall intensity in soil of $1 \mathrm{E}-6 \mathrm{~m} / \mathrm{sec}$ permeability

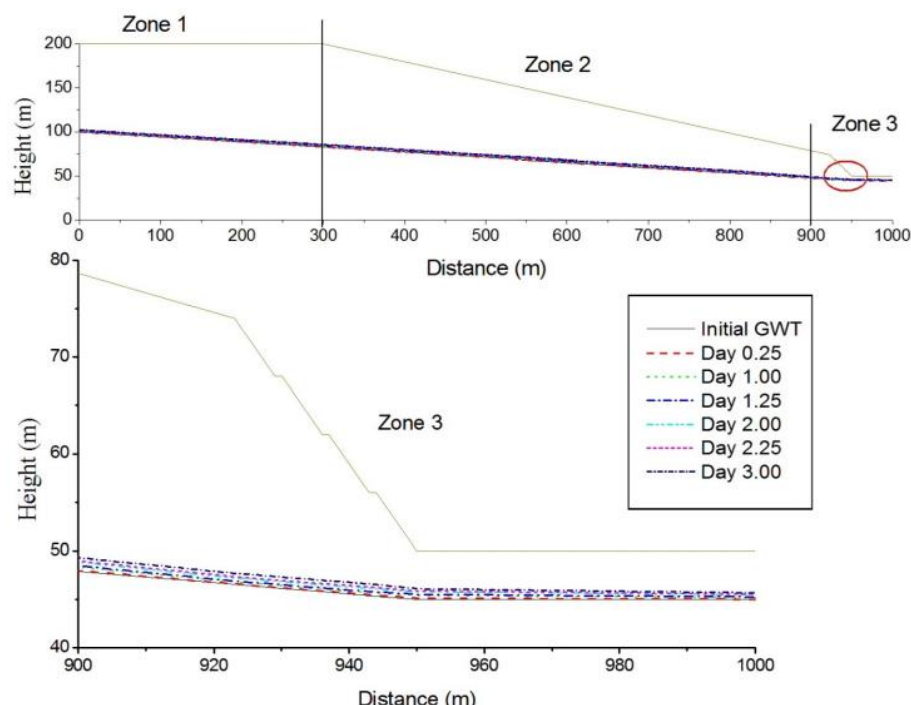

Fig. 6: The rise of GWT after $0.2,0.4, \& 0.6 \mathrm{~m} /$ day rainfall intensity in soil of $1 \mathrm{E}-7 \mathrm{~m} / \mathrm{sec}$ permeability
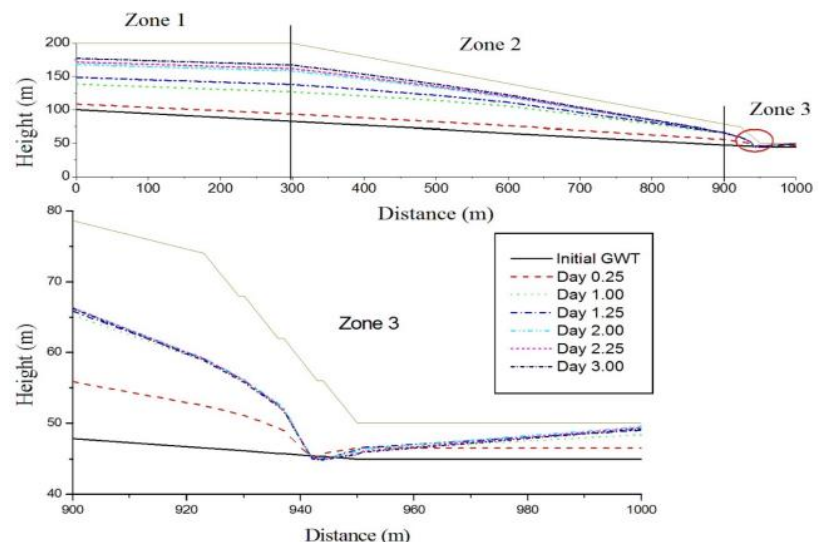

Fig. 7: The rise of groundwater for $0.2,0.4$, and $0.6 \mathrm{~m} /$ day rain intensity for slope with high soil permeability and Pumping of $0.864 \mathrm{~m} /$ day.

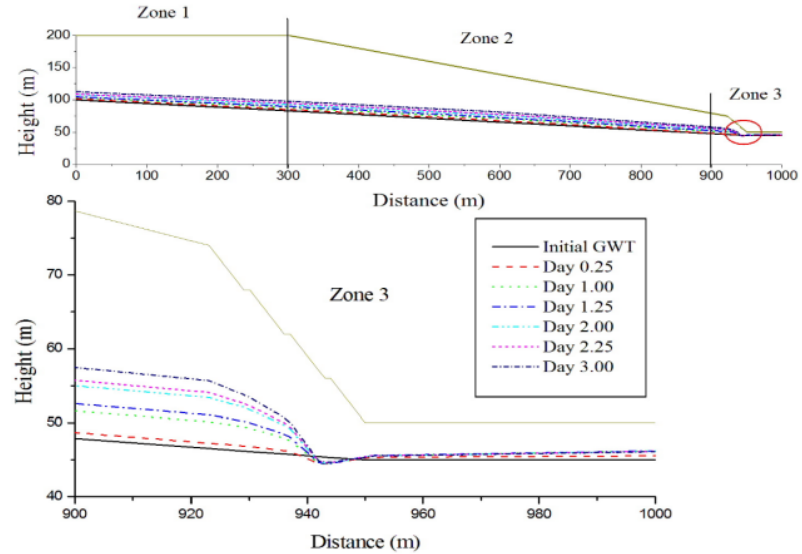

Fig. 8: The rise of groundwater for $0.2,0.4$, and $0.6 \mathrm{~m} /$ day rain intensity for slope with moderate soil permeability and Pumping of $0.0864 \mathrm{~m} / \mathrm{day}$

\subsection{The Drop of Factor of Safety Due To the Rise of Groundwater Table}

It is clear that the rise of groundwater table due to the rainfall at far field may trigger landslide as shown in Fig. 9a where the factor of safety drops to 0.95 in one day. The factor of safety drops just after the first rainfall event from 1.312 to 1.239 at the end of the first rainfall event and 0.95 at the end of the first day for slope with high permeability soil. Groundwater pumping enhances the slope stability and the factor of safety decreases slightly at the end of the first day to 1.294 and levels up until the end of the third day as shown in Fig. 9. Figure 10 shows the slip surface and the factor of safety for slope without pumping groundwater [a] and with 
pumping groundwater at the end of the third day. For the slope with moderate soil permeability [1E- $6 \mathrm{~m} / \mathrm{s}]$, the factor of safety declines from 1.314 to 1.158 at the end of the third while it remains stable with pumping ground water. The factor of safety does not change with low soil permeability slope [1E-7] as the rise of groundwater is slight and does not touch the slip surface in both cases.
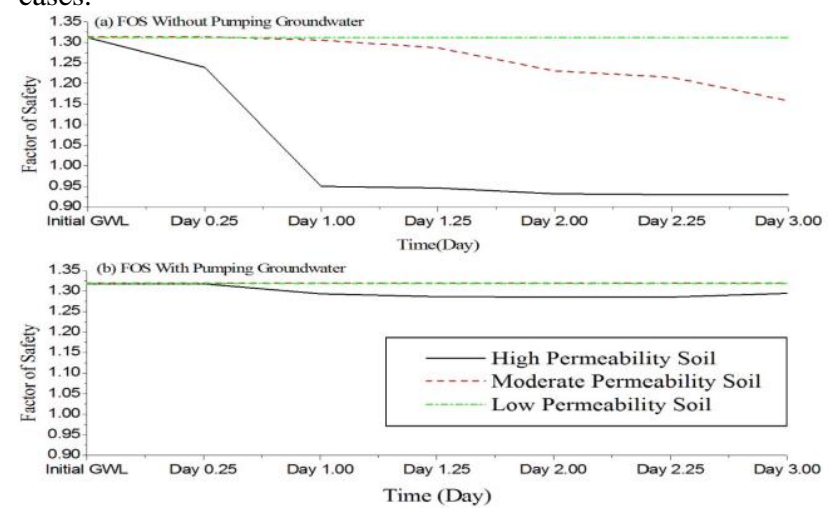

Fig. 9: The resulted factor of safety for the slope [a] without pumping groundwater and $[\mathrm{b}]$ with pumping.

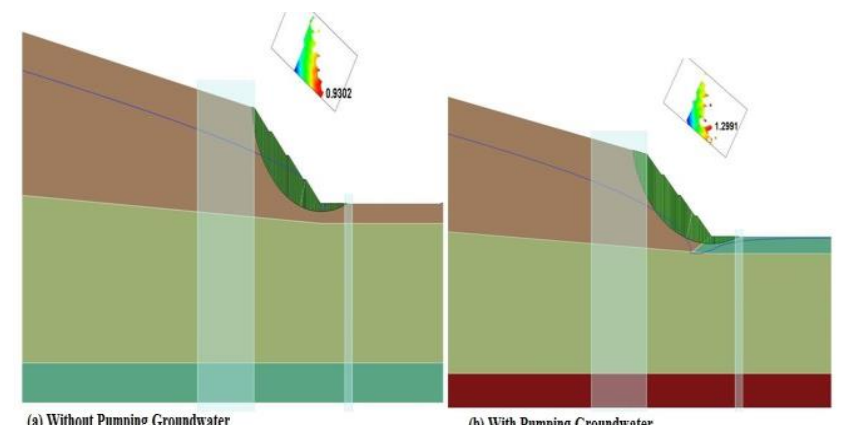

Fig. 10: The factor of safety at the end of the third day for high soil permeability soil slope [a] without Pumping groundwater and [b] with pumping groundwater

\section{Conclusion}

The groundwater table rises due to the rainwater infiltration, the high permeable soil allows much rainwater to reach the groundwater table and cause a quick rise of groundwater level. The quick rise of groundwater may trigger a landslide even though the rain occurs at far field from the slope. The rise of groundwater may induce landslide just after a few hours of the rain event. Slopes with moderate or low soil permeability may fail due to the rise of groundwater table after one or two days of the rain event because of the time taken for the rainwater to infiltrate and the developed perched water tables to dissipates to the main groundwater table. The effect of rain intensity on deep groundwater table is symmetrical because the rainwater decreases while infiltration and almost the same quantity reach the groundwater table but a large perched water develops with high rain intensity that causes the groundwater table to rise for days after the rain event.

The application of groundwater withdrawal system is effective in enhancing the slope stability and avoiding the slope failure induced by the rise of groundwater table.

\section{Acknowledgement}

The authors are thankful to Universiti Teknologi PETRONAS, for their assistantship [GA], supports, and providing favorable research environment and facilities. This project is supported by Ministry of Higher Education, Malaysia [FRGS].

\section{References}

[1] De Vita P, Reichenbach P, Bathurst J, Borga M, Crosta G, Crozier $\mathrm{M}$, et al. Rainfall-triggered landslides: a reference list. Environmental Geology. 1998;35[2]:219-33.

[2] Li WC, Lee LM, Cai H, Li HJ, Dai F, Wang ML. Combined roles of saturated permeability and rainfall characteristics on surficial failure of homogeneous soil slope. Engineering Geology. 2013:153:105-13.

[3] Beyabanaki SAR, Bagtzoglou AC, Anagnostou EN. Effects of groundwater table position, soil strength properties and rainfall on instability of earthquake-triggered landslides. Environmental Earth Sciences. 2016;75[4]:1-13.

[4] Tsaparas I, Rahardjo H, Toll DG, Leong EC. Controlling parameters for rainfall-induced landslides. Computers and Geotechnics. 2002;29[1]:1-27.

[5] Rahardjo H, Santoso VA, Leong EC, Ng Y, Tam C, editors. Porewater pressure characteristics of two instrumented residual soil slopes. Proc of 4th Asia-Pacific Conf on Unsaturated Soils; 2009.

[6] Qi S, Vanapalli SK. Hydro-mechanical coupling effect on surficial layer stability of unsaturated expansive soil slopes. Computers and Geotechnics. 2015;70:68-82.

[7] $\mathrm{Ng} \mathrm{C}$, Shi Q. A numerical investigation of the stability of unsaturated soil slopes subjected to transient seepage. Computers and geotechnics. 1998;22[1]:1-28.

[8] Chae B, Lee J, Park H, Choi J. A method for predicting the factor of safety of an infinite slope based on the depth ratio of the wetting front induced by rainfall infiltration. Natural Hazards and Earth System Sciences. 2015;15[8]:1835-49.

[9] Ali A, Huang J, Lyamin A, Sloan S, Cassidy M. Boundary effects of rainfall-induced landslides. Computers and Geotechnics. 2014;61:341-54

[10] Orense RP. Slope failures triggered by heavy rainfall. Philippine Engineering Journal. 2004;25[2].

[11] Uchaipichat A. Variation of safety factor with suctions of infinite clay slope under partially saturated condition. ARPN Journal of Engineering and Applied Sciences. 2013;8[3]:166-8.

[12] Ishak MF, Ali N, Kassim A. Tree induced suction on slope stabilization analysis. ARPN Journal of Engineering and Applied Sciences. 2016;11[11]:7204-8.

[13] Gasmo J, Rahardjo H, Leong EC. Infiltration effects on stability of a residual soil slope. Computers and Geotechnics. 2000;26[2]:14565.

[14] Galeandro A, Doglioni A, Simeone V, Šimůnek J. Analysis of infiltration processes into fractured and swelling soils as triggering factors of landslides. Environmental earth sciences. 2014;71[6]:2911-23.

[15] Tiwari B, Caballero S. Experimental Modeling of Rainfall Induced Slope Failures in Compacted Clays. IFCEE 20152015. p. 1217-26.

[16] Li WC, Dai F, Wei YQ, Wang ML, Min H, Lee LM. Implication of subsurface flow on rainfall-induced landslide: a case study. Landslides. 2015:1-15.

[17] Tsuchida T, Athapaththu A, Kawabata S, Kano S, Hanaoka T, Yuri A. Individual landslide hazard assessment of natural valleys and slopes based on geotechnical investigation and analysis. Soils and Foundations. 2014;54[4]:806-19.

[18] Leung A, Sun H, Millis S, Pappin J, Ng C, Wong H. Field monitoring of an unsaturated saprolitic hillslope. Canadian Geotechnical Journal. 2011:48[3]:339-53.

[19] Bordoni M, Meisina C, Valentino R, Lu N, Bittelli M, Chersich S. Hydrological factors affecting rainfall-induced shallow landslides: From the field monitoring to a simplified slope stability analysis. Engineering Geology. 2015;193:19-37.

[20] Patuti IM, Rifa'i A, Suryolelono KB. MECHANISM AND CHARACTERISTICS OF THE LANDSLIDES IN BONE BOLANGO REGENCY, GORONTALO PROVINCE, INDONESIA. International Journal. 2017;12[29]:1-8.

[21] Ismail MAM, Ng SM, Abustan I. Parametric study of horizontal drains for slope stability measure: A case study in Putrajaya, Malaysia. KSCE Journal of Civil Engineering.1-6.

[22] Rahardjo H, Hritzuk K, Leong EC, Rezaur R. Effectiveness of horizontal drains for slope stability. Engineering Geology. 2003;69[3]:295-308.

[23] Tsao T, Wang M, Chen M, Takeuchi Y, Matsuura S, Ochiai H. A case study of the pore water pressure fluctuation on the slip surface using horizontal borehole works on drainage well. Engineering geology. 2005;78[1]:105-18.

[24] Cai F, Ugai K, Wakai A, Li Q. Effects of horizontal drains on slope stability under rainfall by three-dimensional finite element analysis. Computers and Geotechnics. 1998;23[4]:255-75. 
[25] D'Acunto B, Urciuoli G. Groundwater regime in a slope stabilized by drain trenches. Mathematical and computer modelling. 2006;43[7]:754-65.

[26] D'Acunto B, Parente F, Urciuoli G. Numerical models for 2D free boundary analysis of groundwater in slopes stabilized by drain trenches. Computers \& Mathematics with Applications. 2007;53[10]:1615-26

[27] Tiwari B, Tran D, Ajmera B, Carrilo Y, Stapleton J, Khan M, et al., editors. Effect of Slope Steepness, Void Ratio, and Intensity of Rainfall on Seepage Velocity and the Stability of Slopes. Geotechnical and Structural Engineering Congress 2016.

[28] Han B, Hou SS, Zhu B, Wang LC, Li A, Ye HJ, editors. Deformation Monitoring and Prediction of a Reservoir Landslide in Sichuan Province, China. Applied Mechanics and Materials; 2014: Trans Tech Publ.

[29] Pirone M, Papa R, Nicotera MV, Urciuoli G. In situ monitoring of the groundwater field in an unsaturated pyroclastic slope for slope stability evaluation. Landslides. 2015;12[2]:259-76.

[30] Tohari A, Nishigaki M, Komatsu M. Laboratory rainfall-induced slope failure with moisture content measurement. Journal of Geotechnical and Geoenvironmental Engineering. 2007;133[5]:575-87.

[31] Tiwari B, Lewis A, editors. Experimental Modeling of Rainfall and Seismic Activities as Landslide Triggers. GeoCongress 2012: State of the Art and Practice in Geotechnical Engineering; 2012: ASCE.

[32] Kassim A, Gofar N, Lee LM, Rahardjo H. Modeling of suction distributions in an unsaturated heterogeneous residual soil slope. Engineering Geology. 2012;131:70-82. 